Robert B. Forbes MD FRCPC, ${ }^{*}$ David J. Murray MD, * David L. Dull MD, * Larry T. Mahoney Mo†

\title{
Haemodynamic effects of rectal methohexitone for induction of anaesthesia in children
}

\begin{abstract}
Pulsed Doppler and two-dimensional echocardiography were used to determine the haemodynamic effects of rectal methohexitone in 12 children $32.4 \pm 3.8$ months old and weighing $13.3 \pm$ $1.1 \mathrm{~kg}$ (mean $\pm S E M$ ). Heart rate, blood pressure and echocardiographic measurements of cardiac output, stroke volume and left ventricular end-diastolic and end-systolic volumes were obtained prior to the induction of anaesthesia. Anaesthesia was induced with $25 \mathrm{mg} \cdot \mathrm{kg}^{-1}$ two per cent rectal methohexitone. Immediately following the onset of sleep all cardiovascular measurements were repeated. Following the induction of anaesthesia with rectal methohexitone there was a significant increase in heart rate. Blood pressure, cardiac index, stroke volume and ejection fraction were unchanged. It is concluded that rectal administration of two per cent methohexitone for the induction of anaesthesia in healthy paediatric patients has minimal haemodynamic effect.
\end{abstract}

\section{Key words}

ANAESTHESIA: paediatric; ANAESTHETIC TECHNIQUES: induction; PREMEDICATION: rectal, methohexitone; HEART: myocardial function, anaesthetics; MEASUREMENT TECHNIQUES: echocardiography, Doppler, twodimensional.

From the Department of Anesthesia* and the Department of Pediatricst University of Iowa College of Medicine, Iowa City, Iowa 52242.

Presented at the 1988 Canadian Anaesthetists' Society Annual Meeting, Halifax, N.S.

Address correspondence to: Dr. R.B. Forbes, Department of Anesthesia, University of Iowa Hospitals and Clinics, lowa City, Iowa 52242.
The rectal administration of methohexitone is a safe and effective technique for the induction of anaesthesia in children. ${ }^{1.4}$ Because the bioavailability of rectally administered methohexitone is low when compared with intravenous administration, ${ }^{5,6}$ relatively large doses of methohexitone must be used to insure that a prompt, reliable onset of sleep is achieved. ${ }^{7,8}$ The haemodynamic response to the administration of short-acting barbiturates is complex and includes a decrease in mean arterial pressure and cardiac output and an increase in heart rate. ${ }^{9-11}$ Myocardial depression and alterations in vascular tone may both contribute to the hypotension that was seen in clinical investigations of adults. ${ }^{9-11}$ Extrapolation of the results of these haemodynamic studies to the paediatric patient is difficult and little information is available that adequately evaluates the haemodynamic effects of intravenous or rectal administration of short-acting barbiturates in children. The large doses of rectal methohexitone required for induction of anaesthesia in paediatric patients may have important haemodynamic consequences, particularly because plasma methohexitone concentrations vary widely with this induction technique. Therefore, the purpose of this investigation was to determine, noninvasively, the haemodynamic changes produced by induction of anaesthesia with rectal methohexitone in children.

\section{Methods}

Twelve ASA physical status I or II children, less than five years of age and scheduled for elective surgery, were studied after the protocol was approved by the institution. al Human Studies Committee and informed parental consent was obtained.

All patients were unpremedicated and accompanied to the presurgical care unit by their parents. Approximately 15 minutes before the induction of anaesthesia, heart rate by ECG and blood pressure by automated oscillotonometry (Dinamapp ${ }^{(2)}$ were determined. In addition, in each patient, left ventricular area and length in systole and diastole were assessed by two-dimensional echocardiog- 
raphy and pulmonary artery blood flow velocity was measured using pulsed Doppler echocardiography. Following completion of the initial two-dimensional and pulsed Doppler studies, anaesthesia was induced by the rectal administration of $25 \mathrm{mg} \cdot \mathrm{kg}^{-1}$ methohexitone.

The methohexitone was prepared by dissolving $500 \mathrm{mg}$ sodium methohexitone in $25 \mathrm{ml}$ sterile water to form a two per cent solution which was instilled through a soft, plastic catheter inserted approximately $5 \mathrm{~cm}$ into the rectum. Parents remained with their children and comforted them until the child was asleep. For the purposes of this investigation sleep was defined as loss of consciousness, unresponsiveness to verbal stimuli and absence of voluntary movement when unstimulated. Immediately following the onset of sleep all haemodynamic measurements were repeated.

The two-dimensional and pulsed Doppler echocardiographic measurements were performed with the patient in the supine position using the technique described by Murray et al. ${ }^{12,13}$ An Ultra Imager 2600 (Biosound, Inc., Indianapolis) mechanical sector scanner with a $5-\mathrm{MHz}$ single element transducer and a 3.5-MHz Doppler interrogation frequency was used to obtain short-axis views at the levels of the high papillary muscle of the left ventricle and great vessels, as well as an apical four-chamber view. Studies were recorded on videotape and later left ventricular cross-sectional area and left ventricular length were measured at the level of the papillary muscles and in the apical four-chamber views, respectively. Pulmonary artery diameter was measured directly above the semilunar valve.

Pulmonary artery blood flow velocity was measured by directing the Doppler probe parallel to pulmonary artery blood flow and a pulsed Doppler wave was directed to collect a flow measure from within the pulmonary artery. This sample was measured above the pulmonic valve and averaged over three cardiac contractions to determine mean pulmonary artery blood flow velocity. Continuously updated two-dimensional images, Doppler profiles, and ECG tracings were displayed on a video monitor and recorded on tape.

Selective frozen images were recorded on a strip-chart for measurement by the ultrasonographer. Using a microsonic CAD-886 image processing and video quantifications system (Microsonics, Inc., Indianapolis), images were traced along the endocardium using the leading edge method. Left ventricular area and length were then used to calculate left ventricular volume at end-systole and end-diastole. Cardiac output was determined from the pulmonary artery diameter and mean velocity of pulmonary artery blood flow. ${ }^{14-17}$

The pre-induction haemodynamic measurements were compared with the haemodynamic values following
TABLE I Demographic data (mean \pm SEM)

\begin{tabular}{lc}
\hline Age & $32.4 \pm 3.8$ months \\
Weight & $13.3 \pm 1.1 \mathrm{~kg}$ \\
Body surface area & $0.56 \pm 0.03 \mathrm{~m}^{2}$ \\
Sleep time & $7.9 \pm 0.5 \mathrm{~min}$ \\
\hline
\end{tabular}

administration of rectal methohexitone using the paired $t$ test or, if the data were not normally distributed, the Wilcoxon signed ranks test. The Shapiro-Wilk test was used to test normality of the data. Statistical significance was accepted at $P<0.05$. All values are expressed as mean \pm SEM.

\section{Results}

The mean age and weight of the children studied were $32.4 \pm 3.8$ months (range 10-57 months) and $13.3 \pm 1.1$ $\mathrm{kg}$ (range 7.1-19.1 kg) (Table I). Eleven children were asleep within $15 \mathrm{~min}$ and the time to the onset of sleep was $7.9 \pm 0.5$ minutes (range 7-11 min). One child, although very sedated, did not fall asleep following the administration of methohexitone and post-induction haemodynamic measurements were obtained $15 \mathrm{~min}$ after administration of the drug in this child.

Following the rectal administration of $25 \mathrm{mg} \cdot \mathrm{kg}^{-1}$ methohexitone the heart rate increased significantly above awake values. Systolic, diastolic and mean blood pressures were unchanged. Cardiac index, stroke volume, left ventricular end-diastolic and end-systolic volumes, and ejection fraction did not change significantly from the pre-induction echocardiographic and pulsed Doppler measurements (Table II). No apnoea or arterial desaturation occurred following the onset of sleep and no other complications were encountered.

\section{Discussion}

The haemodynamic response to the intravenous injection of short-acting barbiturates is complex. Most authors have reported an increase in heart rate and a decrease in mean arterial pressure and cardiac index following the

TABLE II Cardiovascular data before and following rectal methohexitone (mean \pm SEM)

\begin{tabular}{lcc}
\hline & Pre-induction & Post-induction \\
\hline Heart rate (beats $\left.\cdot \min ^{-1}\right)$ & $113 \pm 6.6$ & $126 \pm 4.5^{*}$ \\
Mean blood pressure $(\mathbf{m m H g})$ & $73 \pm 2.4$ & $68 \pm 2.0$ \\
Cardiac index $\left(\mathrm{L} \cdot \mathrm{min}^{-1} \cdot \mathrm{m}^{-2}\right)$ & $2.86 \pm 0.2$ & $3.07 \pm 0.18$ \\
Left ventricular end-diastolic & & \\
$\quad$ volume $(\mathrm{ml})$ & $24.4 \pm 3.2$ & $24.9 \pm 3.4$ \\
Stroke volume $(\mathrm{ml})$ & $13.3 \pm 1.7$ & $13.9 \pm 1.4$ \\
Ejection fraction & 0.56 & 0.57 \\
\hline
\end{tabular}

$P<0.05$. Pre-induction vs post-induction. 
administration of methohexitone in animals and humans. ${ }^{9-11,18,19}$ In this study we demonstrated that the rectal administration of $25 \mathrm{mg} \cdot \mathrm{kg}^{-1}$ methohexitone in children results in an increase in heart rate following the onset of sleep with no significant change in cardiac index, stroke volume and systolic, diastolic, or mean arterial pressure.

Laishley et al ${ }^{8}$ used rectal methohexitone in combination with atropine for induction of anaesthesia in children and also found an increase in heart rate following the onset of sleep. The tachycardia seen in Laishley's patients continued to increase for $30 \mathrm{~min}$ after administration of the methohexitone-atropine solution at which time peak plasma atropine concentrations would be expected to occur following rectal administration of atropine. ${ }^{20}$ Therefore, it is likely that some of the tachycardia seen in Laishley's study was a result of the anticholinergic effect of atropine. Laishley did not measure changes in cardiac output, stroke volume or ejection fraction in his study.

An increase in heart rate may occur if airway obstruction, which is a potential complication of this technique, results in changes in oxygenation or alveolar ventilation. ${ }^{21}$ The children in this study were carefully observed to prevent airway obstruction and pulse oximetry was used to monitor oxygenation following the onset of sleep. Ventilation by clinical assessment was adequate and no child became apnoeic. However, if $\mathrm{PaCO}_{2}$ increased significantly, associated sympathetic stimulation may have caused the increase in the heart rate that was observed.

In other studies the haemodynamic changes that occurred following intravenous thiopentone were affected by both the depth of anaesthesia achieved and by the rate of drug administration. Deeper levels of anaesthesia, as determined by EEG burst-suppression, were associated with greater decreases in cardiac output and blood pressure. ${ }^{22}$ Slower induction of anaesthesia using incremental doses of thiopentone, rather than rapid bolus administration, also produced less profound haemodynamic effects. ${ }^{22,23}$ Following rectal administration of methohexitone the onset of sleep is usually achieved within $15 \mathrm{~min}$, coincident with peak plasma methohexitone concentrations. ${ }^{4,5}$ Although rectal and intravenous administration of methohexitone produce similar peak plasma concentrations, ${ }^{4,5}$ the relatively slower rise in plasma concentration that follows rectal administration of methohexitone may lessen the haemodynamic effects that are seen. Also, although methohexitone inhibits sympathetic nervous activity, the barostatic reflexes remain active, ${ }^{10}$ and this too may contribute to the cardiovascular stability seen following rectal methohexitone. Although baroreceptor stimulation secondary to vasodilatation has been suggested as a cause of increased heart rate follow- ing methohexitone, ${ }^{11,18,19}$ no change in blood pressure or left ventricular end-diastolic volume was seen. This suggests that methohexitone may have a direct cardiac effect causing the increase in heart rate.

In this study pulsed Doppler and two-dimensional echocardiography were used to determine the haemodynamic effects of rectal administration of two per cent methohexitone in children. Induction of anaesthesia with rectal methohexitone resulted in an increase in heart rate following the onset of sleep, but no significant decrease in blood pressure, stroke volume, cardiac index, or ejection fraction. Because these findings are based upon the evaluation of healthy children, extrapolation of the results to paediatric patients with hypovolaemia, congenital heart disease or other associated medical conditions should be made with caution. We conclude that rectal administration of methohexitone for the induction of anaesthesia in healthy paediatric patients has minimal haemodynamic effect.

\section{Acknowledgements}

The authors gratefully acknowledge Motomi Mori for her assistance with the statistical analysis and Sara Paul for her expert preparation of the manuscript.

\section{References}

1 Orallo $M O$, Eather $K F$. Sodium methohexital as a rectal agent in pediatric anesthesia: a controlled comparison with sodium thiamylal. Anesth Analg 1965; 44: 97-103.

2 Budd DC, Dornette WHL, Wright JF. Methohexital for rectal basal narcosis. Anesth Analg 1965; 44: 222-5.

3 Goresky GV, Steward DJ. Rectal methohexitone for induction of anaesthesia in children. Can Anaesth Soc J 1979; 26: 213-5.

4 Liu LMP, Gaudreault P, Friedman PA, Goudsouzian NG, Liu $P L$. Methohexital plasma concentrations in children following rectal administration. Anesthesiology 1985; 62: 567-70.

5 Björkman S, Gabrielsson J, Quaynor $H$, Corbey $M$. Pharmacokinetics of IV and rectal methohexitone in children. Br J Anaesth 1987; 59: 1541-7.

6 DeBoer AG, deleede LGJ, Breimer DD. Drug absorption by sublingual and rectal routes. Br J Anaesth 1984; 56: 69-82.

7 Forbes RB, Vandewalker GE. Comparison of two and ten per cent rectal methohexitone for induction of anaesthesia in children. Can J Anaesth 1988; 35: 345-9.

8 Laishley $R S, O^{\prime}$ Callaghan AC, Lerman J. Effects of dose and concentration of rectal methohexitone for induction of anaesthesia in children. Can Anaesth Soc J 1986; 33: 427-32. 
9 Conway $C M$, Ellis $D B$. The haemodynamic effects of short-acting barbiturates. Br J Anaesth 1969; 41: 534-42.

10 Skovsted $P$, Price $M L$, Price $H L$. The effects of shortacting barbiturates on arterial pressure, preganglionic sympathetic activity and barostatic reflexes. Anesthesiology 1970; 33: 10-8.

11 Bernhoff A, Eklund B, Kaijser L. Cardiovascular effects of short-term anaesthesia with methohexitone and propanidid in normal subjects. $\mathrm{Br} J$ Anaesth 1972; 44: 2-7.

12 Murray DJ, Vandewalker GE, Matherne GP, Mahoney $L T$. Pulsed doppler and two-dimensional echocardiography: comparison of halothane and isoflurane on cardiac function in infants and small children. Anesthesiology 1987; 67: 211-7.

13 Murray DJ, Forbes RB, Murphy KP, Mahoney LT. Nitrous oxide: cardiovascular effects in infants and small children during halothane and isoflurane anesthesia. Anesth Analg 1988; 67: 1059-64.

14 Goldberg SJ, Sahn DJ, Allen HD, Valdes-Cruz LM, Hoenecke $H$, Carnahan $Y$. Evaluation of pulmonary and systemic blood flow by 2-dimensional doppler echocardiopgraphy using fast Foumier transform spectral analysis. Am I Cardiol 1982: 50: 1394-1400.

15 DiSessa TG, Friedman WF. Echocardiographic evaluation of cardiac performance. Cardiol Clin 1983; 1: 487-99.

16 Mercier JC, DiSessa TG, Jarmakani JM et al. Twodimensional echocardiograpic assessment of left ventricular volumes and ejection fraction in children. Circulation 1982; 65: 962-9.

17 Torroledo FA, Quinones MA, Fernandez GC, Waggoner $A D$, Winters WL. Quantification of left ventricular volumes by two-dimensional echocardiography: a simplified and accurate approach. Circulation 1983; 67: 579-84.

18 Lamalle $D$. Cardiovascular effects of various anesthetics in man. Acta Anaesth Belg 1976; 27: 208-24.

19 Rowlands DJ, Howitt G, Logan WFWE, Clarke AD. Jackson $P W$. Haemodynamic changes during methohexitone anaesthesia in patients with supraventricular arthythmias. Br J Anaesth 1967; 39: 554-9.

20 Olsson GL, Bejersten A, Feychting H, Palmer L, Pettersson $B-M$. Plasma concentrations of atropine after rectal administration. Anaesthesia 1983; 38: 1179-82.

21 Larsson LE, Nilsson K. Andreasson S, Ekstrom-Jodal $B$. Effects of rectal thiopentone and methohexitone on carbon dioxide tension in infant anaesthesia with spontaneous ventilation. Acta Anaesthesiol Scand 1987; 31: 227-30.
22 Fieldman EJ, Ridley RW, Wood EH. Hemodynamic studies during thiopental sodium and nitrous oxide anesthesia in humans. Anesthesiology 1955; 16: 473-89.

23 Seltzer JL, Gerson JI, Allen FB. Comparison of the cardiovascular effects of bolus $v$, incremental administration of thiopentone. $\mathrm{Br}$ J Anaesth 1980; 52: 527-9.

\section{Résumé}

Nous avons utilisé un appareil à échographie bi-dimensionnelle couplé à un Doppler pulsé pour mesurer l' impact hémodynamique du méthohexital par voie rectale chez 12 enfants de $32.4 \pm$ 3.8 mois pesant $13.3 \pm 1.1 \mathrm{~kg}$ (moyenne \pm erreur-type). $\mathrm{La}$ dose d'induction de l'anesthésie était de $25 \mathrm{mg} \cdot \mathrm{kg}^{-1}$ d'une solution d deux pour cent. Nous mesurions la fréquence cardiaque, la pression artérielle, le débil cardiaque et les volumes télésystoliques et télé-diastoliques du ventricule gauche juste avant l'induction et dès la perte de conscience de l'enfant. Avec l'induction, le pouls s'est accéléré mais la pression arterielle, l'index cardiaque et les volume et fraction d' ejection $n$ 'ont pas changé. Il semble donc que l' induction de l'anesthésie avec du méthohexital deux pour cent par voie rectale ait peu d'effets hémodynamiques chez les enfants en santé. 